\title{
Structural cell wall proteins from five pollen species and their relationship with boron
}

\author{
Edith del R. García-Hernández ${ }^{1, *}$ and Gladys I. Cassab López ${ }^{2}$ \\ ${ }^{1}$ Departamento de Preparatoria Agrícola, Universidad Autónoma Chapingo, Km 36.5 Carretera Mexico-Texcoco, Chapingo, Texcoco, México, \\ 56230; '2Biología Molecular de Plantas, Instituto de Biotecnología, UNAM, Av. Universidad 2001, Cuernavaca, Morelos, 62210, México. \\ *Corresponding autor: edithrg@correo.chapingo.mx
}

Received: 05/10/2005, Accepted 20/01/2006

Boron (B) is an essential micronutrient for the survival of vascular plants. The most severe effect derived from a deficiency of $\mathrm{B}$ is the alteration of cell wall biogenesis and pollen germination. We investigated pollen of plant species that require B for germination (Zea may L. and Nicotiana tabacum L.), as well as those that can germinate without B (Pinus sp, Lilum longiflorum, Impatiens sp.). In both groups, B addition in the growth medium increased the length of the pollen tube after germination. Hydroxyproline Rich Glycoproteins (HRGPs) are the most abundant cell wall structural proteins of dicotyledonous plants and the sexual tissues of monocotyledonous plants. Here, we show that maize pollen accumulated a significant pool of hydroxyproline (Hyp) and 63\% of this amino acid was localized in the pollen tube wall. Maize pollen germinated in the presence of B accumulated soluble (48\%) and non-soluble (16\%) Hyp in the pollen tube wall in contrast to maize pollen germinated without B. In addition, B seems to modify the amount of HRGPs that become cross-linked to the wall. Immunolocalization of HRGPs showed that these glycoproteins were preferentially localized in the pollen tube of maize, not in the pollen grain itself. Hence, B might affect the assembling of HRGPs in the wall of pollen tubes grown in vitro.

Key words: cell wall, HRGPs, hydroxyproline, pollen tube.

Proteínas estruturais da parede celular do pólen de cinco espécies e sua relação com o boro: Boro (B) é um micronutriente essencial para a sobrevivência das plantas vasculares. O efeito mais drástico derivado da sua deficiência é a alteração na biogênese da parede celular durante a germinação de pólen. Investigamos pólen de espécies de plantas que requerem B para germinar (Zea may L. e Nicotiana tabacum L.), e de outras que podem germinar na sua ausência (Pinus sp, Lilum longiflorum, Impatiens sp.). Em ambos os grupos, a adição de B no meio de germinação aumentou o comprimento do tubo polínico depois da germinação. Glicoproteínas ricas em hidroxiprolina (HRGPs) são as mais abundantes proteínas estruturais da parede celular de dicotiledôneas e do tecido sexual de monocotiledôneas. Aqui, mostrou-se que pólen de milho acumulou uma significativa quantidade de hidroxiprolina (Hyp), estando 63\% desse aminoácidos localizados na parede do tubo polínico. Pólen de milho germinado na presença de B acumulou Hyp solúvel (48\%) e não solúvel (16\%) na parede do tubo polínico, em contraste ao pólen germinado na ausência de B. Adicionalmente, B parece modificar a quantidade de HRGPs que se ligam à parede celular. Imunolocalização de HRGPs mostrou que essas glicoproteínas estavam preferencialmente localizadas na parede do tubo polínico de pólen de milho, mas não no pólen. B, portanto, pode afetar no arranjo de HRGPs na parede de tubos polínicos crescidos in vitro.

Palavras-chave: hidroxiprolina, HRGPs, parede celular, tubo polínico.

\section{INTRODUCTION}

Plant cell walls are a structural metabolically dynamic complex that contains a vast amount of polysaccharides and proteins with unusual physical and chemical properties.
Hydroxyproline Rich Glycoproteins (HRGPs) are the most abundant cell wall structural proteins in dicotyledonous plants and sexual tissues of monocotyledonous plants (Sommer-Knudesen et al., 1997; Cassab and Varner, 1998). 
They contain highly repetitive sequence domains in which hydroxyproline (Hyp) is a major amino acid (Showalter, 1993). Extensins are the most extensively studied HRGPs of plants, making up 1-10\% of the primary cell wall (Cassab and Varner, 1988).

Boron (B) is an essential micronutrient element for vascular plants and diatoms; however, its mechanism of action is not yet understood (Matoh 1997; Blevins and Lukaszewski, 1998). Many studies have implicated B in the biogenesis of plant membranes and cell walls (Goldbach et al., 1991; Bonilla et al., 1997). Deficiency symptoms first appear in actively growing tissues, within hours in root tips, and within minutes or seconds in pollen tube tips, and are characterized by cell wall abnormalities (Loomis and Durst, 1992; Blevins and Lukaszewski, 1998). However, it has been observed that in most plant species the $\mathrm{B}$ requirement for reproductive growth is much higher than for vegetative growth. The most dramatically rapid manifestation of $\mathrm{B}$ deficiency is seen in pollen tube growth. Without B, the pollen tubes of most species burst explosively, always at the outermost tip, ejecting large amounts of their contents. Growth of pollen tubes requires a continuing presence of $\mathrm{B}$. Pre-germination treatment with B stimulates germination of pollen but does not maintain the integrity of the growing pollen tubes (Schmucker 1933, 1934). In general, Scmucker's results support a role of B as a cell wall crosslinker since B deficiency occurred specifically at the pollen tube tips, showing weakness of the newly formed wall. In fact, B is cross-linked with the rhamnoglacturonan (RG) II fraction of pectic polysaccharides in many plant species $(\mathrm{Hu}$ and Brown 1994; Kobayashi et al., 1996; Matoh et al., 1996 O'Neill et al., 1996). On the other hand, other candidates for borate crosslinking in primary cell walls are HRGPs and PRPs (Bonilla et al., 1997). However B seems to participate in membrane structure since it can form complexes with membrane constituents such as glycolipids and/or glycoproteins (Shkolnik, 1984; Cakmak et al., 1995). So far, the results of pollen growth studies are consistent with Bcomplexing cell wall polymers, while the lipid thermostability results show that $\mathrm{B}$ is important in membrane structure and function (Jackson, 1989). Whatever the mechanism, the role of $\mathrm{B}$ in reproductive growth is particularly striking.

Pollen grains of most species are naturally low in $\mathrm{B}$, but in the styles, stigma, and ovaries, B concentration is usually high (Gauch and Dugger, 1954). However, there have been too few B measurements to substantiate this claim (Dell and Huang, 1997). The uniformly high B requirement for reproductive growth across the plant kingdom is intriguing and indicates similarities between reproductive structures, so unlike other plant cell walls perhaps the composition of the pollen tube is similar across plant species (Blevins and Lukaszewski, 1998). Pex 1 is a pollen-specific extensinlike domain protein, involved in pollen tube growth that is expressed in starch-filled (mature) and in germinating pollen of maize (Rubinstein, et al., 1995b). Hence the pollen tube constitutes a good model to study processes related to cell wall protein assembly. In our study, we report that B affected the deposition of HRGPs into the pollen tube cell wall. This information may be important for understanding the mechanisms by which B controls reproductive growth in plants.

\section{MATERIAL AND METHODS}

Biological material and germination trials: Fresh pollen from maize (Zea mays L), tobacco (Nicotiana tabacum), Impatiens $s p$. and lily (Lilium longiflorum.) was immediately germinated after collection under two B conditions: B deficient medium (-B), (18\% sucrose; $2 \mathrm{mM} \mathrm{CaCl}_{2} ; 0.5 \%$ agar) and B sufficient medium (+B) $(18 \%$ sucrose; $2 \mathrm{mM}$ $\mathrm{CaCl}_{2}$ and the following concentrations of boric acid: in Impatiens sp. $0.5 \mathrm{mM}$; in maize $1.0 \mathrm{mM}$; in tobacco $1.6 \mathrm{mM}$; pine $1.66 \mathrm{mM}$ and in lily $0.162 \mathrm{mM}$. Pollen was considered to have germinated when the pollen tube was at least half as large as the grain length. Thirty trials were carried out on three different samples of each species; pollen observation was made with a stereoscopic microscope (Leika stereo zoom 6 Photo). The data on pollen germination and tube length were processed with the SAS software using the Tukey test for the comparison of means at $\mathrm{P} \leq 0.05$.

Chemical analysis: All pollen samples were freeze-dried in a lyophilizer, when dry weights were determined. The quantity of hydroxyproline $\left(\mathrm{Hyp}_{\mathrm{Tot}}\right)$, hydroxyproline extractable in $\mathrm{CaCl}_{2}\left(\mathrm{Hyp}_{\mathrm{Ext}}\right)$, and non-soluble hydroxyproline (Hyp $\left.\mathrm{Hns}_{\text {Ins }}\right)$ in pollen tubes and pollen grains was determined by a colorimetric method (Drozdz et al. 1976), as follows: dry tissue was hydrolyzed in $6 \mathrm{~N} \mathrm{HCl}\left(3 \mathrm{~h}\right.$ at $\left.120^{\circ} \mathrm{C}\right)$ and then the samples dried thoroughly under vacuum with a $\mathrm{NaOH}$ trap. The hydrolysates were resuspended in $100 \mu \mathrm{l}$ of $\mathrm{H}_{2} \mathrm{O}$ and centrifuged in a microfuge to eliminate humus. To each sample and each HyPro standard $(0.5 \mu \mathrm{g}$ and $0.05 \mu \mathrm{g}$ in 100 ul) $60 \mu \mathrm{l}$ of the acetate-citrate buffer $(0.1 \mathrm{~g}$ chloramine $\mathrm{T}$; $1.0 \mathrm{ml} \mathrm{H}_{2} \mathrm{O} ; 2.0 \mathrm{ml}$ acetate-citrate buffer) was added and 10 
minutes later $120 \mu \mathrm{l}$ of the second solution was added (1.0 $\mathrm{ml}$ of $72 \%$ perchloric acid; $5.0 \mathrm{ml}$ PDMAB solution $[6 \% \mathrm{w} / \mathrm{v}$ paradimethylaminobenzaldehyde (PDMAB) in isopropanol]. The tubes were then promptly placed in a hot water bath at $60^{\circ} \mathrm{C}$ for 20 minutes. This allows the colour to develop, and the absorbance was read in a spectrophotometer at $560 \mathrm{~nm}$. The pollen $\mathrm{Hyp}_{\mathrm{Tot}}$ level was obtained from grains hydrolyzed in $6 \mathrm{~N} \mathrm{HCl}\left(120^{\circ} \mathrm{C}, 3 \mathrm{~h}\right.$. $)$.

Cell wall isolation. Pollen tubes were ground in a glass homogenizer and treated as described by Cassab et al. (1985).

Distribution of Hyp. The distribution of Hyp in pollen tubes was determined in germinated pollen from maize in the presence of $0.5 \mathrm{mM}, 1.0 \mathrm{mM}$ and $2.0 \mathrm{mM}$ of boric acid for $2 \mathrm{~h}$. First, pollen tubes were separated from pollen grains by briskly vortexing the solution, the pollen tubes were collected after filtering the solution through a $10 \mu \mathrm{m}$ nylon mesh. To measure the quantity of Hyp Tot $_{\text {the sample was }}$ hydrolyzed using $6 \mathrm{~N} \mathrm{HCl}\left(120^{\circ} \mathrm{C}, 3 \mathrm{~h}\right.$. $)$, and evaluated by the colorimetric method (Drodz et al., 1976) described above. A fraction of the lyophilized sample was resuspended in $0.2 \mathrm{M} \mathrm{CaCl}_{2}\left(\mathrm{Hyp}_{\mathrm{Sol}}\right)$ for $12 \mathrm{~h}$. at $4^{\circ} \mathrm{C}$, then the Hyp content was measured. The non-soluble material was lyophilized, weighed and hydrolyzed $\left(\mathrm{HCl} 6 \mathrm{~N}, 120^{\circ} \mathrm{C}, 3 \mathrm{~h}\right)$, and $\mathrm{Hyp}_{\text {Ins }}$ was also quantified. The data for total hydroxyproline $\left(\mathrm{Hyp}_{\mathrm{Tot}}\right)$, hydroxyproline extractable in $\mathrm{CaCl}_{2}\left(\mathrm{Hyp}_{\mathrm{Ext}}\right)$, and non-soluble hydroxyproline $\left(\mathrm{Hyp}_{\mathrm{Ins}}\right)$ were processed with the SAS software using the Tukey test for the comparison of means at $\mathrm{P} \leq 0.05$.

Western blot and immunolocalization of HRGPs: Extractable proteins in $0.2 \mathrm{M} \mathrm{CaCl}_{2}$ from pollen tubes grown on $-\mathrm{B}$ and $+\mathrm{B}$ were boiled in an equal volume of $2 \mathrm{X}$ SDS sample buffer $(0.1 \mathrm{M}$ Tris, $\mathrm{pH}$ 6.8, 1.8\% SDS, 18 [w/v] glycerol, $9 \%[\mathrm{w} / \mathrm{v}]$ 2-mercaptoethanol, $0.02 \%[\mathrm{v} / \mathrm{v}]$ bromophenol blue) and submitted to electrophoresis on SDS-PAGE gels (12\%), using $4 \mu \mathrm{g}$ of protein for each sample. Protein content was determined by the Bradford method (1976) and silver nitrate was used as a stain. Proteins were electroblotted onto nitrocellulose paper (Hybond-C, Amersham) in a semi-dry medium (SemiPhor, Hoeffer) membrane, hydrated with a transfer buffer. The membrane was soaked with the primary HRGP antibody (Cassab and Varner, 1987) for $12 \mathrm{~h}(1: 1300$ dilution) dissolved in buffer $(0.2 \%$ BSA, $0.1 \%$ Tween- 20 , $0.013 \mathrm{M}$ Tris, $\mathrm{pH} 7.5,0.15 \mathrm{M} \mathrm{NaCl}$ ), washed three times in wash buffer $(0.01 \%$ [v/v] tween-20, $0.013 \mathrm{M}$ Tris $\mathrm{pH} 7.5$,
$0.15 \mathrm{M} \mathrm{NaCl}$ ), and finally incubated for 1 hour with the secondary antibody conjugated to alkaline phosphatase (antirabbit IgG, Zymed AP-Goat rabbit IgG). Colour reaction took place in the presence of alkaline phosphatase buffer.

For HRGPs immunolocalization, pollen tubes were fixed in FAA [10\% (v/v) formaldehyde, $5 \%(\mathrm{v} / \mathrm{v})$ acetic acid, and $50 \%$ ethanol] and mounted onto glass slides pre-treated with poly-lysine (Sigma). The primary antibody used was anti-HRGPs from soybean seed coats (Cassab and Varner, 1987) diluted 1:50, and the immunogold reagent 1:100 (ImmunoResearch), with which the sections were incubated 4 $\mathrm{h}$, respectively, at room temperature. The secondary antibody was goat anti-rabbit IgG horseradish peroxidase diluted 1: 100 with which sections were incubated for $4 \mathrm{~h}$ at room temperature, and the immunogold-silver staining performed as described by Springall et al. (1984). The negative control involved the substitution of the primary HRGP antibody with preimmune serum and anti-profilin antibody from bean, diluted 1:1000 and 1:50 respectively. Pollen tubes were visualized using a Zeiss Axioskop light microscope and photographed using ASA 100 Kodacolor film.

\section{RESULTS}

We studied the effect of $\mathrm{B}$ on in vitro pollen germination from different plants species. The results reported in table 1 showed that pollen germination of maize and tobacco pollen grains increased when B was present in growth medium, and henceforth these species were designated B dependent (Bd), whereas Impatiens sp., pine and lily pollen germination rates were less sensitive to $\mathrm{B}$, and were designated $\mathrm{B}$ independent (Bi). However, the length of all pollen tubes analyzed was doubled in the presence of $+\mathrm{B}$ medium (table 2 ).

The content of $\mathrm{Hyp}_{\mathrm{Tot}}$ differed in pollen grains from maize, tobacco, pine and Impatiens sp. (table 3). The content of $\mathrm{Hyp}_{\mathrm{Tot}}$ in pollen from maize and tobacco (Bd) turned out to be $30 \%$ greater than that of pine, Impatiens $s p$., and lily (Bi). The value of $\mathrm{Hyp}_{\mathrm{Tot}}$ for lily was similar to that of Impatiens $s p$. Therefore, there is not a strict correlation between high Hyp $\mathrm{Tot}_{\text {in }}$ pollen of $\mathrm{Bd}$ species as opposed to $\mathrm{Bi}$ species (table 3).

To evaluate the relationship between the B tube growth response and HRGP accumulation in the pollen tube wall, maize pollen was selected because of its: a) pollen tube size, b) high germination percentage and c) ease in separating the pollen tube from the pollen grain. We examined the distribution of Hyp in cell wall extracts, and isolated cell walls of maize pollen tubes (table 4). 
Table 1. Pollen germination of different plant species in $(+B)$ and (-B) Impatiens sp., $0.5 \mathrm{mM}$; maize $1.0 \mathrm{mM}$, tobacco $1.66 \mathrm{mM}$ pine, lily $0.162 \mathrm{mM}$ of boric acid. The data are the means of six replicates.

\begin{tabular}{lcc}
\hline Plant & $\begin{array}{l}\text { Sufficient medium }+\mathrm{B} \\
\% \text { Pollen germination }\end{array}$ & $\begin{array}{c}\text { Deficient medium }-\mathrm{B} \\
\% \text { Pollen germination }\end{array}$ \\
\hline Impatiens $s p$. & $14.7( \pm 3.9) \mathrm{a}$ & $13.9( \pm 4.3) \mathrm{a}$ \\
Zea mays & $75.1( \pm 5.6) \mathrm{a}$ & $5.3(+2.3) \mathrm{b}$ \\
Pinus sp. & $74.6( \pm 6.7) \mathrm{a}$ & $70.8( \pm 6.9) \mathrm{a}$ \\
Nicotiana tabacum & $67.3( \pm 3.1) \mathrm{a}$ & $21.1( \pm 4.5) \mathrm{b}$ \\
Lilium longiflorum & $17.6( \pm 3.6) \mathrm{a}$ & $13.1( \pm 3.9) \mathrm{a}$ \\
\hline
\end{tabular}

Mean values in columns with the same letter are not significantly different, according to the Tukey test at $\mathrm{P}<0.05$.

Table 2. Pollen tube length ( $\mu \mathrm{m})$ of different species, for pollen grains germinated in boron deficient medium $(-\mathrm{B})$ and boron sufficient medium $(+\mathrm{B})$. Time $(\mathrm{h})$ that pollen was incubated in the germination medium: ${ }^{1}(8) ;{ }^{2}(2) ;{ }^{3}(24),{ }^{4}(9),{ }^{5}(6)$.

\begin{tabular}{lcc}
\hline Plant & $\begin{array}{c}\text { Sufficient medium }+\mathrm{B} \\
\text { Tube length }(\mu \mathrm{m})\end{array}$ & $\begin{array}{c}\text { Deficient medium }-\mathrm{B} \\
\text { Tube length }(\mu \mathrm{m})\end{array}$ \\
\hline Impatiens sp. $^{1}$ & $260.5( \pm 53) \mathrm{a}$ & $128.7( \pm 61) \mathrm{b}$ \\
Zea mays $^{2}$ & $457.3( \pm 64) \mathrm{a}$ & $130.2(+28) \mathrm{b}$ \\
Pinus sp. $^{3}$ & $122.4( \pm 20) \mathrm{a}$ & $61.5( \pm 15) \mathrm{b}$ \\
Nicotiana tabacum $^{4}$ & $624.7( \pm 93) \mathrm{a}$ & $154.1( \pm 47) \mathrm{b}$ \\
Lilium longiflorum $^{5}$ & $1235.6( \pm 234) \mathrm{a}$ & $704.1( \pm 124) \mathrm{b}$ \\
\hline
\end{tabular}

Mean values in columns with the same letter are not significantly different, according to the Tukey test at $\mathrm{P}<0.05$.

Table 3. Total Hydroxyproline levels (Hyp $\mathrm{Tot}_{\mathrm{To}}, \mu \mathrm{g}$ Hyp/mg dry weight) in pollen from different plant species.

\begin{tabular}{lc}
\hline Pollen & $+\mathrm{B}$ \\
\hline Impatiens sp. & $0.87( \pm 0.03) \mathrm{c}$ \\
Zea mays & $1.01( \pm 0.06) \mathrm{b}$ \\
Nicotiana tabacum & $1.31( \pm 0.07) \mathrm{a}$ \\
Pinnus sp. & $0.68( \pm 0.03) \mathrm{d}$ \\
Lilium longiflorum & $0.89( \pm 0.06) \mathrm{c}$ \\
\hline
\end{tabular}

Mean values in columns with the same letter are not significantly different, according to the Tukey test at $\mathrm{P}<0.05$.
Since an optimum B concentration increased the levels of Hyp in both $\mathrm{Hyp}_{\text {Ext }}(48 \%)$ and $\mathrm{Hyp}_{\text {Insol }}(16 \%)$ with respect to the control fractions, it was then of interest to determine whether B modifies the accumulation of HRGPs in pollen tubes. For this, a western blot analysis was performed on cell wall proteins of pollen tubes grown in the presence and absence of $\mathrm{B}$, using a specific anti-HRGP antibody from soybean seed coats. This antibody is highly specific for HRGPs of both dicotyledonous and monocotyledonous plants, and does not cross react with arabino-galactan proteins, another class of HRGPs (Cassab and Varner, 1987). Cell wall fractions from pollen grains grown under -B conditions showed two high molecular weight bands. In contrast, the cell wall fraction from pollen grains grown on the $+\mathrm{B}$ medium did not contain polypeptides that were labeled by the HRGP antibodies (figure 1B).

To determine the localization of HRGPs in germinated maize pollen, we performed immunolocalization studies with anti-HRGP antibodies from soybean seed coats (figures 2A-D). In maize germinated pollen grains, HRGPs were primarily detected in the pollen tube wall which corresponds with the chemical analysis of Hyp in pollen tubes (table 4A). The detection of HRGPs in maize pollen tubes was very strong, although the antibody was not obtained from a monocotyledonous plant.

\section{DISCUSSION}

One of the major effects derived from the lack of B occurs during pollen germination and the formation of pollen tube (Loomis and Durst, 1992). Pollen grains of most species require a continuous supply of B (Steer and Steer, 1989; Taylor and Hepler, 1997). It has been reported that pollen from most plant species requires B to germinate (Bd); however pollen from some plant species germinates almost equally well in a B deficient environment (Bi) (table 1.) (Heslop-Harrison,

Table 4. Distribution of Hydroxyproline (Hyp) in maize pollen tube cell walls.

(A) Total hydroxyproline $\left(\mathrm{Hyp}_{\mathrm{Tot}}\right) \mu \mathrm{g}$ Hyproxyproline/mg pollen tube dry weight

$$
\begin{gathered}
0.5 \mathrm{mM} \mathrm{H}_{3} \mathrm{BO}_{3} \\
0.53( \pm 0.03) \mathrm{c}^{\mathrm{z}}
\end{gathered}
$$$$
1.0 \mathrm{mM} \mathrm{H}_{3} \mathrm{BO}_{3}
$$

$$
0.63( \pm 0.03) \mathrm{a}
$$

$2.0 \mathrm{mM} \mathrm{H}_{3} \mathrm{BO}_{3}$ $0.63( \pm 0.03) \mathrm{a}$

(B)

Extractable hydroxyproline in $\mathrm{CaCl}_{2}\left(\mathrm{Hyp}_{\mathrm{Ext}}\right) \mu \mathrm{g}$ Hydroxyproline/ $\mu \mathrm{g} 0.2 \mathrm{M} \mathrm{CaCl}_{2}$

$$
\begin{gathered}
0.5 \mathrm{mM} \mathrm{H}_{3} \mathrm{BO}_{3} \\
0.13( \pm 0.02) \mathrm{c}
\end{gathered}
$$

(C)

$$
\begin{gathered}
0.5 \mathrm{mM} \mathrm{H}_{3} \mathrm{BO}_{3} \\
1.73( \pm 0.02) \mathrm{c}
\end{gathered}
$$

\section{$2.0 \mathrm{mM} \mathrm{H}_{3} \mathrm{BO}_{3}$}

$0.16( \pm 0.02) \mathrm{b}$

Non-soluble hydroxyproline $\left(\operatorname{Hyp}_{\text {Ins }}\right) \mu \mathrm{g}$ Hydroxyproline/ mg pollen tube dry weight $1.0 \mathrm{mM} \mathrm{H}_{3} \mathrm{BO}_{3}$ $4.15( \pm 0.03) \mathrm{a}$
$2.0 \mathrm{mM} \mathrm{H}_{3} \mathrm{BO}_{3}$

$2.69( \pm 0.03) \mathrm{b}$

Mean values in columns with the same letter are not significantly different, according to the Tukey test at $\mathrm{P}<0.05$. 
1971; Jackson, 1989). In addition, many physiological effects of B deficiency have been identified in the plant cell, such as impairments of sugar transport, membrane integrity, RNA metabolism, etc. (Heslop-Harrison, 1987; Cakmak and Römheld, 1997). The initial phase of germination includes processes that lead to the onset of pollen tube growth, when Bd species seem to be more sensitive to B deficiency, since their germination percentages diminished 13 times in maize and 3 times in Nicotiana (table 1).

On the other hand, pollen tube length from plant species utilized in these studies was increased after the addition of B (table 2). Previous studies have shown that the wall in the tip region of the pollen tube is mainly composed of pectins (Mascarenhas, 1993). The synthesis and modification of the pectic network is an active process directly associated with the complex boron-RGII-calcium (O'Neill et al., 1996). This suggests that the elongation and growth of the pollen tube is a consequence of this association (Kobayashi, et al., 1999).

Reports suggest that the B requirement of plants is determined by the RGII content of its cell wall. It has been shown that one gram of monocot cell wall contains $6 \%$

A

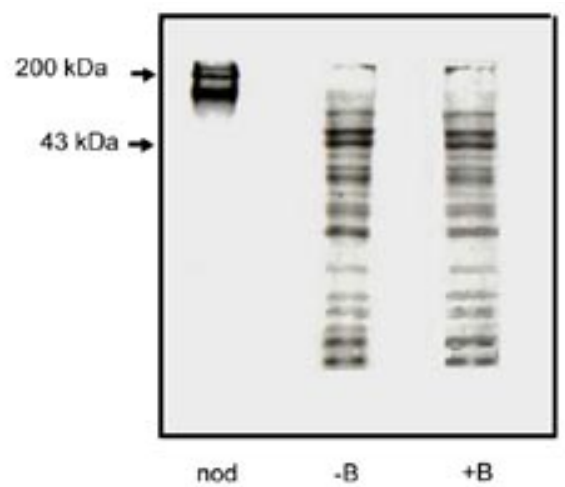

\section{B}

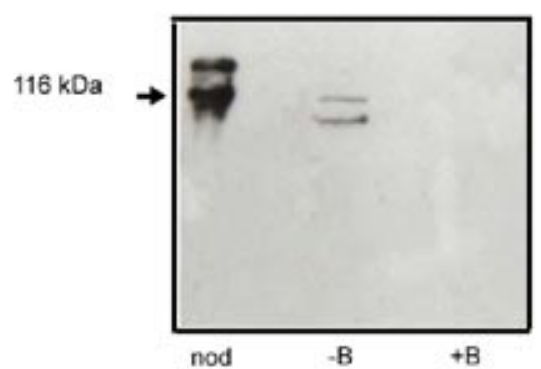

Figure 1. Characterization of extractable cell wall fractions from maize pollen tubes. (A) Cell wall salt-extractable proteins from maize pollen tubes grown in sufficient $+B$ and deficient -B media. (B) Western blot analysis of maize pollen tubes. The blots were probed with anti-HRGPs antibodies from soybean seed coat. Note that two HRGP glycoprotein bands for material grown in media $-\mathrm{B}$ were not observed in $+\mathrm{B}$. of RGII and this could only covalently bind $8 \% \mu \mathrm{mol} \mathrm{B}$ considering dicot cell walls as $100 \%$ (O'Neill, 1996). Thus, the $\mathrm{B}$ pollen requirement could be determined by differences between pollen tube cell walls of $\mathrm{Bi}$ and $\mathrm{Bd}$. In order to confirm this, we should evaluate a greater number of pollen plants species of the Bd and Bi types and measure the RGII fraction in both groups of plants.

Hydroxyproline was present in all pollen grain species tested, but the content of $\mathrm{Hyp}_{\mathrm{Tot}}$ in pollen from maize and tobacco turned out to be $30 \%$ greater than pine, Impatiens $s p$., and lily. However, further evaluation must be carried out to confirm this fact. Previous studies have suggested that HRGPs are abundant in sexual tissues since the presence of higher amounts of Hyp in the pollen and pollen tube has been reported.(Li et al., 1994; Rubinstein et al., 1995a; Jauh and Lord, 1996). In addition to their structural role, it has been suggested that pollen HRGPs could play roles in sexual recognition and signalling (Rubinstein, 1995b).

HRGPs are the most abundant structural proteins in maize sexual tissues and since (Hyp) is an amino acid resulting from post-translational modification that characterizes HRGPs, their protein level can be indirectly estimated when the Hyp concentration is quantified (Cassab and Varner, 1987; Kieliszewski and Lamport, 1994). Measurement of hydroxyproline levels have been utilized primarily in the study of cell walls since only trace amounts of hydroxyproline are found in the cytoplasmic fraction (Rubinstein et al., 1995a). The level of Hyp in the pollen tube wall of maize changed depending upon the $\mathrm{B}$ concentration in the growing medium (table 4A-C). The importance of HRGPs in cell walls of pollen tubes was evident, since $63 \%$ of $\mathrm{Hyp}_{\mathrm{Tot}}$ from the maize pollen is located in the tube. This suggests that most of the Hyp in the grain was used for the construction of the cell wall during germination (table 4A). This value was high, considering that the pollen tube length in pollen germinated in vitro was up to $70 \%$ shorter than the length reached in vivo (Taylor and Hepler, 1997). At an optimal B concentration (1 $\mathrm{mM})$, the level of total, extractable and insoluble Hyp was larger than at the other B concentrations tested (table 4). This suggests that an optimal concentration of B can facilitate the accumulation of HRGPs in the cell wall (Bonilla et al., 1997).

Previous studies have described the biochemical and physiological relationship between $\mathrm{B}$ and pectic substances, although little is known about the effect of B in plant cell wall assembly of HRGPs (Matoth et al., 1996; Matoth et al., 1997). Western blot analysis of cell wall proteins from 
pollen tubes grown in the presence and absence of B (figure 1 ), suggested that in the presence of $B$, HRGPs might be modified and hence the specific HRGP antibodies did not recognize them. This alteration could be due to insolubility of HRGPs in the wall in the presence of $\mathrm{B}$, or to the formation of a linkage between B and HRGPs, or both. It has been reported that HRGPs are slowly insolubilized into the cell wall by a covalent link (Qi et al., 1995). Furthermore, previous data showed that HRGPs are not covalently bound to the walls of B deficient nodules of soybean root, suggesting that B may have a role in the assembly of some wall protein components in nodules (Bonilla et al., 1997). Although there is an abundance of HRGP in the pollen tubes, only the maize pollen extensin-chimera PEX1 has been so far molecularly characterized. PEX1 seems to play a role in pollen tube growth during pollination (Rubinstein, et al., 1995b). Further investigations are essential to explain the assembly of the HRGPs in growing pollen tubes, and their relation with the B-RGII complex.

The accumulation of HRGPs in germinated pollen of maize grown in $-\mathrm{B}$ and $+\mathrm{B}$ was studied by immunocytochemical analysis (figure 2). HRGPs are deposited in the emerging pollen tube wall in enormous quantities, but there
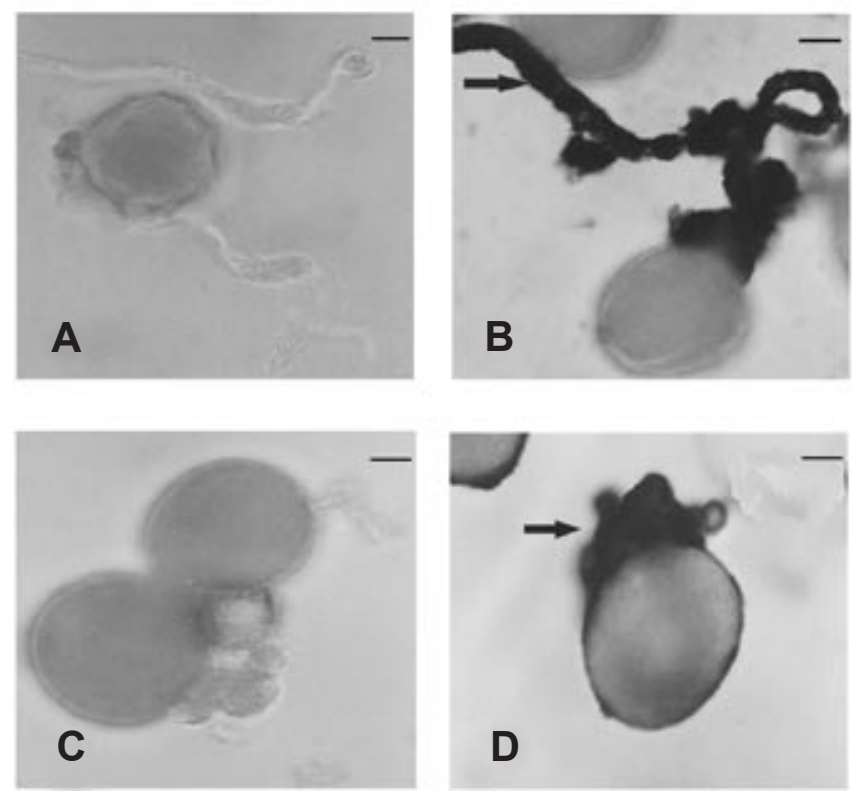

Figure 2. Immunolocalization of HRGPs in germinated pollen grains from maize. (A, C) germinated pollen grains incubated with preimmune serum. (B, D) germinated pollen incubated with anti-HRGPs antibodies from soybean seed coat. $(A, B)$ pollen grains germinated in $+B$. Note that the labeling is associated with the cell wall (arrow) in (B) and the pollen tube burst without boron (D - arrow). is no deposition of these glycoproteins in the pollen grain. It confirms that HRGPs are synthesized previous to germination and deposited in the cell wall of the growing pollen tube (Rubinstein et al., 1995a,c). It has been proposed that the HRGPs might provide structural support for the pollen tube necessary for its rapid growth, and have a role in sexual recognition and signalling during the fertilization (Rubinstein, et al., 1995b). Thus, the study of HRGPs of sexual tissues might help to elucidate the fertilization processes in plants.

As we demonstrated here, colorimetric evaluations of Hyp in maize pollen germinated in $+\mathrm{B}$ conditions indicated that during pollen tube growth there was an enormous amount of HRGPs that are secreted into the wall. In fact, approximately $63 \%$ of the $\mathrm{Hyp}_{\mathrm{Tot}}$ was present in the pollen tube wall. Similar results were obtained with Impatiens $s p$. Hence, B deficiency probably impedes the assembly of HRGPs in the cell wall matrix.

Acknowledgments: We are grateful to Lorena López for her valuable help with the light microscopy analysis. E. G. was supported by fellowship No. 80369 from Consejo Nacional de Ciencia y Tecnología.

\section{REFERENCES}

Blevins DG, Lukaszewski KM (1998) Boron in plant structure and function. Annu. Rev. Plant Physiol. Plant Mol. Biol. 49:481-500.

Bonilla I, Mergold-Villaseñor C, Campos ME, Sanchez N, Perez H, Lopez L, Castrejon L, Sanchez F, Cassab GI (1997) The aberrant cell walls of boron-deficient bean root nodules have no covalently bound hydroxyproline-/prolinerich proteins. Plant Physiol. 115:1329-40.

Bradford MM (1976) A rapid and sensitive method for the quantitation of microgram quantities of protein utilizing the principle of protein-dye binding. Anal. Biochem. 72: 248-254.

Cakmak I, Kurz H, Marschner H (1995) Short-term effects of boron, germanium and high light intensity on membrane permeability in boron deficient leaves of sunflower. Physiol. Plant. 95:11-18.

Cakmak I, Römheld V. (1997) Boron defiency induced impairments of cellular functions in plants. Plant Soil 193:71-83.

Cassab GI (1998) Plant cell wall proteins. Annu. Rev. Plant Physiol. Plant Mol. Biol. 49:281-309.

Cassab GI, Nieto-Sotelo J, Cooper JB, Van Holst GJ, Varner JE (1985) A developmentally regulated hydroxyprolinerich glycoprotein from the cell walls of soybean seed coats. Plant Physiol. 77:532-535.

Cassab GI, Varner JE (1987) Immunocytolocalization of extensin in developing soybean seed coats by immunogoldsilver staining and tissue printing on nitrocelulose paper. J. Cell Biol. 105:2581-88. 
Cassab GI, Varner JE (1988) Cell wall proteins. Annu. Rev. Plant Physiol. Plant Mol. Biol. 39:321-53

Dell B, Huang L (1997) Physiological response of plants to low boron. Plant Soil 193:103-120.

Drozdz M, Kucharaz E, Zyja J. (1976) A colorimetric micromethod for determination of hydroxyproline in blood serum. Z. Med. Labortech. 17:163-71.

Gauch HG, Dugger WM Jr. 1954. The physiological action of boron in higher plants: a review and interpretation. College Park: Univ. Md., Agric. Exp. Stn.

Goldbach HE, Blaser-Grill J, Lindemann N, Porzelt M, Hörrmann C, Lupp B, Gessner B (1991) Influence of boron on net proton release and its relation to other metabolic processes. Curr. Top. Plant Biochem. Physiol. 42:925929.

Heslop-Harrison J (1971) The pollen wall: structure and development. In: Heslop-Harrison J (ed), Pollen: Development and physiology, pp.75-98. Butterworth, London.

Heslop-Harrison J (1987) Pollen germination and pollen-tube growth. Int. Rev. Cytol. 107:1-78.

Hu H, Brown PH (1994) Localization of boron in cell walls of squash and tobacco and its association with pectin. Plant Physiol. 105:681-689.

Jackson JF (1989) Borate control of protein secretion from Petunia pollen exhibits critical temperature discontinuities. Sex. Plant Reprod. 2:11-14.

Jauh GY, Lord EM (1996) Localization of pectins and arabinogalactan proteins in lily (Lilium longiflorum L.) pollen tube and style, and their possible roles in pollination. Planta 199:251-261.

Kieliszewski MJ, Lamport DTA (1994) Extensin: repetitive motifs, functional sites, post-translational codes, and phylogeny. Plant J. 5:157-72.

Kobayashi M, Matoh T, Azuma J (1996) Two chains of rhamnogalacturonan II are cross-linked by borate-diol ester bonds in higher plant cell walls. Plant Physiol. 110: 1017-1020

Kobayashi M, Nakagawa H, Asaka T, Matoh T (1999) Borate- rhamnogalacturonan II bonding reinforced by $\mathrm{Ca} 2+$ retains pectic polysaccharides in higher-plant cell walls. Plant Physiol. 119:199-204.

Li YQ, Chen F, Linskens HF, Cresti M (1994) Distribution of unesterified and esterified pectins in cell walls of pollen tubes of flowering plants. Sex. Plant Reprod. 7:145-152

Loomis WD, Durst R W (1992) Chemistry and biology of boron. Biofactors 3: 229-239.
Mascarenhas JP (1993) Molecular mechanisms of pollen tube growth and differentiation. Plant Cell 5:1303-1314.

Matoh T, Kawaguchi S, Kobayashi M (1996) Ubiquity of a borate-rhamnogalacturonan II complex in the cell walls of higher plants. Plant Cell Physiol. 37:636-640.

Matoh T. (1997) Boron in plant cell walls. Plant Soil 193: 59-70.

O’Neill MA Warrenfeltz D, Kates K, Pellerin P, Doco T, Darvill AG Albersheim P (1996) Rhamnogalacturonan-II, a pectic polysaccharide in the walls of growing plant cell forms a dimer that is covalently cross-linked by a borate ester. In vitro conditions for the formation and hydrolysis of the dimer. J. Biol. Chem. 271:22923-22930.

Qi X, Behrens BX, West PR, Mort J (1995) Solubilization and partial characterization of extensin fragments from cell walls of cotton suspension cultures. (Evidence for a covalent cross-link between extensin and pectin). Plant Physiol. 108:1691-701.

Rubinstein AL, Prata RTN, Bedinger PA (1995a) Developmental accumulation of hydroxyproline and hydroxyproline-containing proteins in Zea mays pollen. Sex. Plant Reprod. 8:27-32.

Rubinstein AL, Broadwater AH, Lowrey KB, Bedinger PA (1995b) Pex1, a pollen-specific gene with an extensin-like domain. Proc. Natl. Acad. Sci. USA 92:3086-3090.

Rubinstein AL, Márquez J, Suárez-Cervera M, Bedinger PA (1995c) Extensin-like glycoproteins in the maize pollen tube wall. Plant Cell 7:2211-2225.

Schmucker T (1933) Zur Blutenbiologie tropischer Nymphaeaarten. II (Bor als entscheidener faktor). Planta 18:641-650.

Schmucker T (1934) Uber den Einfluss von borsaure auf pflanzen insbesonderekeimende pollenkorner. Planta 23: 264-283.

Shkolnik MY (1984) Trace elements in Plants. Elsevier, New York.

Showalter AM (1993) Structure and function of plant cell wall proteins. Plant Cell 5:9-23.

Sommer-Knudsen J, Bacic A, Clarke AE (1997). Hydroxyproline-rich plant glycoproteins. Phytochemistry 47: 483-497.

Springall, D R, Hacker G H, Grimelius L, Polak J M (1984). The potentital of the immunogold-silver staining method for paraffin sections. Histochemistry 81: 603-608.

Steer MW, Steer JM (1989) Pollen tube tip growth. New Phytol. 111:323-358.

Taylor LP, Hepler PK (1997) Pollen germination and tube growth. Annu. Rev. Plant Physiol Plant Mol. Biol. 48: 461-91. 